\title{
The importance of urban sustainable development in a flood threatened area: the case of the northern coast of El Campello (Spain)
}

\author{
J. Valdés-Abellán ${ }^{1}$, A. J. Tenza-Abril ${ }^{1}$, J. M. Ortega ${ }^{1}$ \\ \& E. Sánchez-Camacho ${ }^{2}$ \\ ${ }^{1}$ Departament d'Enginyeria de la Construcció, Obres Públiques e \\ Infraestructura Urbana, Universitat d'Alacant, Spain \\ ${ }^{2}$ Reticulares Alicante, S.L. Alacant, Spain
}

\begin{abstract}
The southeast coast of the Iberian Peninsula (Spain and Portugal), and especially the Costa Blanca, is a very important tourist destination. Tourism has produced intense urban development, and in most cases, buildings and urban zones have occupied an important part of ravine basins. One of the most important climate features of this geographic area is a very intense and localized rainfall. As a consequence of these rainfalls, water levels in ravines are high.

In this work, in order to study the relationship between unsustainable urban development and flood threats, a coastal zone situated in the northern coast of El Campello (Alicante province, Spain) was chosen. Eight ravines flow into the Mediterranean Sea in this area. For each ravine, turnoff thresholds and water levels estimation were calculated for two situations: the first one is the present situation and the second one is a hypothetical initial situation, before the touristic development without urban zones in these basins.

Finally, there is a high decrease of turnoff thresholds and a rise of water levels in the studied basins. Then, it could be concluded that an unsustainable urban development produces an increase of flood threat in the particular case of the Costa Blanca, and in general in the southeast coast of Spain, due to their geographic and climate features.

Keywords: unsustainable urban development, turnoff thresholds, water levels, flood threaten, rainfall, basins, Mediterranean.
\end{abstract}




\section{Introduction}

Nowadays, floods are one of the critical hazards that human beings have to confront. These episodes constitute some of the most severe natural disasters, causing damage to property and infrastructures, often involving the loss of human lives [1]. This statement is particularly true in certain regions, such as the southeast of Spain, due to the combination of a higher frequency of occurrence of these phenomena, inherent in Mediterranean climates, together with an increased vulnerability, as a consequence of important urban development that has taken place associated with the tourist activity [2].

This study is focused on Alicante (Spain), where downpours are extremely heterogeneous [3]. Precipitation totals per storm range from 15-20 $\mathrm{mm}$ to $100 \mathrm{~mm}$ can occasionally exceed this threshold. Normally rainfall totals oscillate between 30 and $70 \mathrm{~mm}$ [4].

El Campello has many basins that share many characteristics with the typical Mediterranean basin with a small area and moderately steep slopes that generate short concentration times and therefore can create dangerous situations.

In the present work it has been calculated that the volume of water that can appear in the eventual rainfall which periodically takes place in this region, in two scenarios: first is the present situation and characteristics of the basin and the second one it is corresponded to the hypothetical original situation, without the urban development.

\section{Methodology}

\subsection{Study area}

The area chosen for the study is located in the coastline (see Figure 1); the municipality of El Campello has $55.27 \mathrm{~km}^{2}$, is slightly elongated SW-NE and is situated on the Costa Blanca. It is bordered by Alicante, San Juan de Alicante, Muchamiel, Busot, Aguas de Busot, Orcheta and Villajoyosa. On its east side, El Campello faces the Mediterranean Sea along $23 \mathrm{~km}$ of coastline, where 10 basins flow into. This paper studies the following basins: El Amerador, Morro Blanc, Enmig, Coveta Fuma, Aguas, La Merced, Baeza and Lanuza. These basins are located between El Campello and Villajoyosa (Figure 1: 1) and all of them have common morphological characteristics.

These basins have a particular trait in common; in the last 3-4 decades they have been subject to a large urban development. This has resulted in highly vulnerable situations and has increased the risk of flooding.

El Campello is situated in the eastern part of the outer zones of the Betic mountain range, and within these in the Prebetic system. This territory is characterized by a certain lithological diversity:

(i) Jurassic and Tertiary Zone, located in the N-NW, where the mountains correspond to Jurassic outcrops. Its reliefs are less rough toward the south, were the Quaternary emerge. 
(ii) Quaternary zone, for the rest of the municipality, from the foothills to the sea and south. It manifests itself as sandy deposits that appear along the Alicante's coast and other recent deposits that correspond with a colluvial and alluvial sediments close to the younger streams [5].
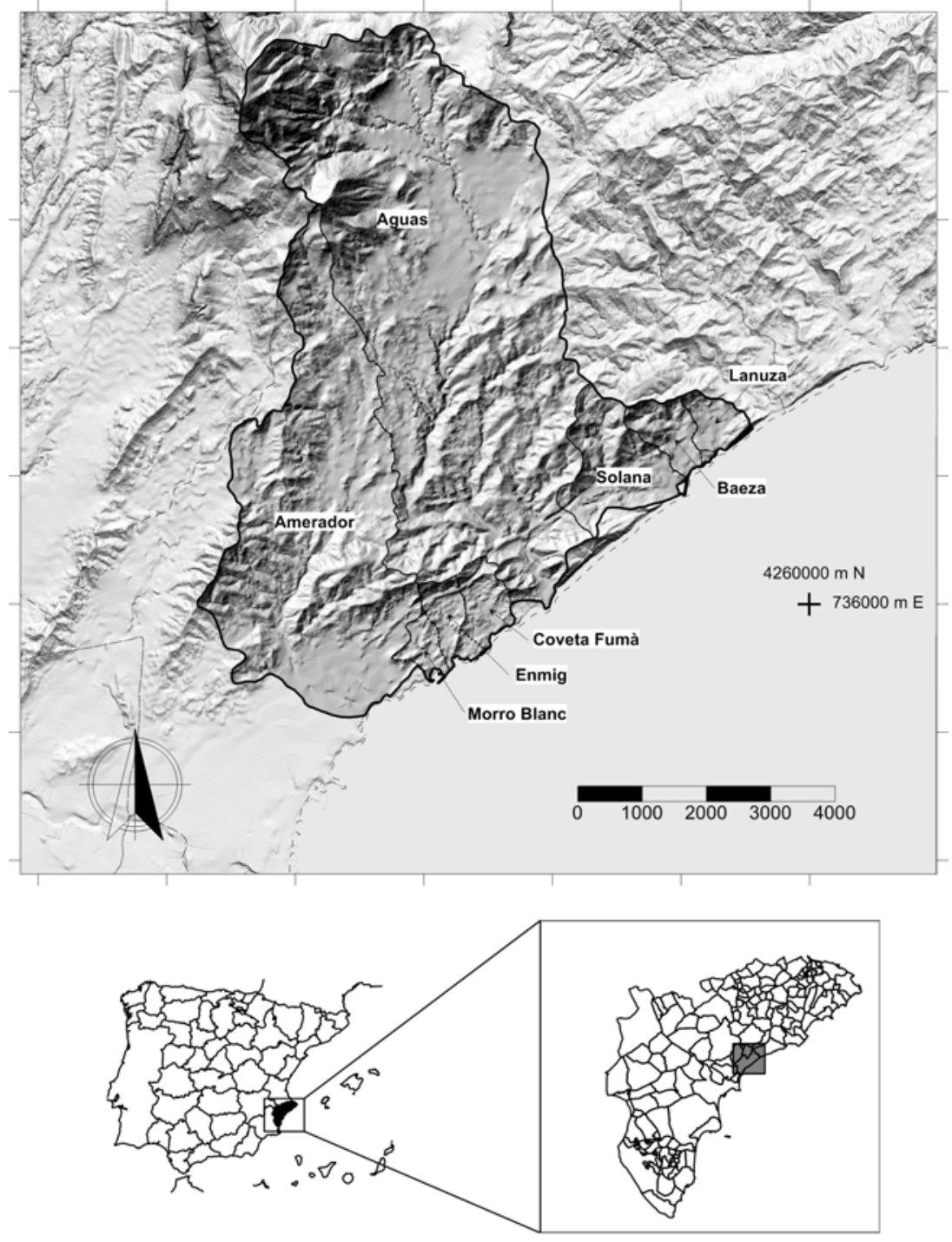

Figure 1: Location of study zone and map with basins and drainage network.

Weather can be classified as Mediterranean subtropical dry and semi-arid, covering littoral and pre-littoral lands of the south of the mountainous border. 
Rainfalls are scarce, irregular and random [6]. The summer drought is extended from 3 to 5 months. The total annual days with rainfall do not exceed 60 , therefore there are days with high-intensity rainstorms [7].

\subsection{Basins characteristics}

The analysis was developed using a 1:10,000 map edited by Cartographic Institute of Valencia, which was the starting point to define the watersheds boundary of the different basins. From this, information of size and shape of basin was calculated, information about elevation of the basins and finally hydrological information.

\subsection{Rainfall assessment}

Firstly the rainfall volume of considerate return period was obtained by two different methods.

The first of these methods uses information of daily rain volumes which are registered by the Spanish Agency of Meteorology (AEMET) in its broad net of meteorological stations laid around the country.

The selection of the meteorological stations to use as sources of information was based on the consideration of different aspects: the distance from the study zone, the characteristics of the relief between station and study area, the quality of the meteorological station and period of time through which records extend.

After these considerations, station of Ciudad Jardin (information from 1950 to nowadays) and Relleu (information from 1962 to nowadays except one year) were considered. A statistical analysis was carried out to assess the precipitation rate associated with a return period of 100 years considering a Gumbel type I distribution of maximum values. The adjustment was validated by the Kolmogorov-Smirnov goodness-of-fit test for both stations.

The second method was based in the document "Máximas lluvias en la España peninsular" [8] edited by the Spanish Government which provides values of maximum precipitation rates by using a SQRT-ET max statistical distribution. This document was edited by the Spanish Government to provide useful information in the complete territory of Iberian Peninsula, filling the areas where does not exist meteorological stations in the vicinity.

Once both values of maximum daily rainfall by the two different methods were available, the highest of both was chosen in order to calculate the water discharge in the ravine for all eight basins.

\subsection{Turnoff thresholds}

Turnoff thresholds were calculated for each basin according to the Spanish roads and highways standard part 5.2-I.C. "Superficial drainage" [9], that, in turn, comes from the S.C.S. model developed by U.S. Conservation Service. Land use information was obtained through the online application GESPLAN [10], developed by regional government of Alicante. This application considers 13 
types of land uses, 4 different kinds of human transformations, 4 kinds of agriculture techniques, 4 levels of natural areas and 1 kind of mining activity.

Firstly, basins turnoff thresholds were calculated for present situation. Secondly, they were calculated again for the hypothetical initial situation. For this situation, areas which nowadays are urbanized were considered as thin forest, because it is the most extended land use in the majority of studied area without urbanizing.

\subsection{Water levels}

Water levels in the mouth of each ravine were obtained by two different methods.

On one hand, the Temez formulation, often referred to as Rational Modified Method [9, 11], was used. This is a hydrometeorological method which gives an estimation of water discharge in the ravine from meteorological information. This method has been used in Spain for many years and its results are acceptable according to real measurements, especially in basins smaller than $50 \mathrm{~km}^{2}$. This method only provides the peak of discharge linked to a certain return period, so users cannot obtain information about the hydrograph.

On the other hand, water levels were also calculated using HEC-HMS software [12], developed by U.S. Army. This software provides as outputs the peak of water discharge and the hydrograph linked to each return period in each of studied ravines. Different kinds of hydrographs can be obtained using HECHMS software, but in this study only SCS hydrograph was studied for each ravine and situation. Rainfalls in southeast of Spain are usually short and very intense. Then, in order to calculate the hydrograph for each ravine, it has been established a one-hour rainfall. This rainfall has three equal intervals with different intensities.

Assessment of these water levels in the mouth of each ravine was made for both present and hypothetical initial situations, in order to study the influence of urban development. The differences between two methods employed were also analyzed.

\section{Results and discussion}

In order to know the influence of urban development in flood vulnerability, turnoff thresholds and water levels were calculated for the present situation and for a hypothetic initial situation. The names of studied ravines are: Amerador, Morro Blanc, Enmig, Coveta Fuma, Aguas, La Solana, Baeza and Lanuza.

The main characteristics of ravine basins, needed to calculate turnoff thresholds and water levels, are shown in Table 1 . The majority of ravine basins have a surface less than $3 \mathrm{~km}^{2}$ and their average slope is higher than $10 \%$. The only exceptions are the ravines of Amerador and Aguas, which present a surface of their basins between $14 \mathrm{~km}^{2}$ and $30 \mathrm{~km}^{2}$, and their average slopes are smaller (around 8\%).

Rainfalls in 24 hours calculated for each basin are shown in Table 2. 
Table 1: $\quad$ Main characteristics of ravine basins.

\begin{tabular}{|c|c|c|c|c|}
\hline Ravine & $\begin{array}{c}\text { Surface of } \\
\text { basin }\left(\mathrm{km}^{2}\right)\end{array}$ & $\begin{array}{c}\text { Length of } \\
\text { ravine }(\mathrm{km})\end{array}$ & $\begin{array}{c}\text { Average slope } \\
\text { of ravine }(\%)\end{array}$ & $\begin{array}{c}\text { Concentration } \\
\text { time }(\mathrm{min})\end{array}$ \\
\hline Amerador & 14.72 & 10.30 & 8.5 & 170 \\
\hline Morro Blanc & 0.45 & 0.97 & 9.6 & 27 \\
\hline Enmig & 0.59 & 1.26 & 15.4 & 31 \\
\hline Coveta Fuma & 0.82 & 1.06 & 15.5 & 27 \\
\hline Aguas & 28.06 & 14.30 & 7.5 & 222 \\
\hline La Solana & 2.37 & 3.25 & 11.8 & 66 \\
\hline Baeza & 0.85 & 1.70 & 17.6 & 37 \\
\hline Lanuza & 0.65 & 1.00 & 11.2 & 27 \\
\hline
\end{tabular}

Table 2: Rainfalls in 24 hours for each ravine basin for 100 years return period.

\begin{tabular}{|c|c|}
\hline Ravine & Rainfall in 24 hours (mm) \\
\hline Amerador & 184 \\
\hline Morro Blanc & 195 \\
\hline Enmig & 195 \\
\hline Coveta Fuma & 195 \\
\hline Aguas & 170 \\
\hline La Solana & 168 \\
\hline Baeza & 168 \\
\hline Lanuza & 168 \\
\hline
\end{tabular}

Turnoff thresholds have changed because parts of the basins are occupied by urban zones. As a consequence of these changes, impervious areas increase and turnoff thresholds decrease. The impervious area at present situation and turnoff thresholds for the hypothetic initial situation and present situation obtained for ravines studied are shown in Table 3.

As can be observed, in most of the ravine basins studied (except Amerador and Aguas), the percentage of impervious areas at present moment is very high, which could be a typical case of non sustainable urban development. For example, this percentage is around $60 \%$ for Coveta Fuma basin and around 50\% for Morro Blanc basin. These basins have small surface, and they are close to the coast. As a consequence, they are more attractive to be transformed into urban zones by tourism.

The water levels in mouth of ravines, calculated according rational method for a 100 years return period, are shown in Table 4. Use of rational method is suggested by the Spanish Roads and Highways standards to design bridges which cross rivers and ravines.

Water levels for each ravines increase between hypothetical initial situation, without urban zones in their basin, and present situation. The highest rises have 
Table 3: $\quad$ Turnoff thresholds and impermeable area of ravines basins.

\begin{tabular}{|c|c|c|c|}
\hline Ravine & $\begin{array}{c}\text { Impermeable area } \\
\text { of basin (\%) } \\
\text { Present situation }\end{array}$ & $\begin{array}{c}\text { Turnoff threshold } \\
\text { Hypothetical } \\
\text { initial situation } \\
(\mathrm{mm})\end{array}$ & $\begin{array}{c}\text { Turnoff threshold } \\
\text { Present situation } \\
(\mathrm{mm})\end{array}$ \\
\hline Amerador & 6.2 & 38 & 35 \\
\hline Morro Blanc & 48.3 & 33 & 14 \\
\hline Enmig & 31.1 & 30 & 18 \\
\hline Coveta Fuma & 63.2 & 36 & 64 \\
\hline Aguas & 1.7 & 65 & 29 \\
\hline La Solana & 24.2 & 38 & 33 \\
\hline Baeza & 24 & 42 & 19 \\
\hline Lanuza & 35.6 & 33 & \\
\hline
\end{tabular}

Table 4: Water levels in the mouth of ravines obtained using a rational method for a return period of 100 years.

\begin{tabular}{|c|c|c|}
\hline Ravine & $\begin{array}{c}\text { Water level } \\
\text { Hypothetical initial } \\
\text { situation }\left(\mathrm{m}^{3} / \mathrm{s}\right)\end{array}$ & $\begin{array}{c}\text { Water level } \\
\text { Present situation }\left(\mathrm{m}^{3} / \mathrm{s}\right)\end{array}$ \\
\hline Amerador & 79.4 & 88.7 \\
\hline Morro Blanc & 6.5 & 14.7 \\
\hline Enmig & 9 & 11.9 \\
\hline Coveta Fuma & 10.9 & 29.3 \\
\hline Aguas & 58.4 & 61.7 \\
\hline La Solana & 15 & 26 \\
\hline Baeza & 7.6 & 12 \\
\hline Lanuza & 7.2 & 15.3 \\
\hline
\end{tabular}

been observed for ravines Morro Blanc, Coveta Fuma and Lanuza. In these cases, water levels obtained for present situation is more than twice as obtained for hypothetical initial situation. These results could mean that an unsustainable urban development produces an increase of water levels in mouth of ravines, and as a consequence, it could also produces an increase of flood threaten, mainly in urban zones placed close to the coast.

Water levels in ravine outfalls have also been calculated using HEC-HMS software, which permits to obtain the hydrograph of ravine. Rainfall temporal distribution for each ravine is shown in Table 5.

Total precipitation of this one-hour rainfall is the same than total precipitation estimated for rainfalls in 24 hours, calculated using a statistical method for 100 years return period (Table 2).

The water levels for each ravine obtained using HEC-HMS are higher than those calculated according to the rational method. This is due to the different duration of rainfalls considered for each method. Nevertheless, duration of 
Table 5: Rainfalls for each ravine considered for HEC-HMS simulations.

\begin{tabular}{|c|c|c|}
\hline Ravine & Time intervals (min) & Precipitation (mm) \\
\hline \multirow{3}{*}{ Amerador } & $0-20$ & 50 \\
\hline & $20-40$ & 100 \\
\hline & $40-60$ & 34 \\
\hline \multirow{3}{*}{ Morro Blanc } & $0-20$ & 40 \\
\hline & $20-40$ & 125 \\
\hline & $40-60$ & 30 \\
\hline \multirow{3}{*}{ Enmig } & $0-20$ & 40 \\
\hline & $20-40$ & 125 \\
\hline & $40-60$ & 30 \\
\hline \multirow{3}{*}{ Coveta Fuma } & $0-20$ & 40 \\
\hline & $20-40$ & 125 \\
\hline & $40-60$ & 30 \\
\hline \multirow{3}{*}{ Aguas } & $0-20$ & 45 \\
\hline & $20-40$ & 90 \\
\hline & $40-60$ & 35 \\
\hline \multirow{3}{*}{ La Solana } & $0-20$ & 43 \\
\hline & $20-40$ & 95 \\
\hline & $40-60$ & 30 \\
\hline \multirow{3}{*}{ Baeza } & $0-20$ & 43 \\
\hline & $20-40$ & 95 \\
\hline & $40-60$ & 30 \\
\hline \multirow{3}{*}{ Lanuza } & $0-20$ & 43 \\
\hline & $20-40$ & 95 \\
\hline & $40-60$ & 30 \\
\hline
\end{tabular}

rainfall considered for HEC-HMS simulations is very similar to real rainfall occurring in the studied zone, so it is expected that results obtained using HECHMS could be more realistic.

The hydrographs obtained in mouth of Ravine Amerador for present and initial situation, using HEC-HMS software, are depicted in Figure 2(A). Both hydrographs and peak water levels are very similar, because only a small part of this basin has been occupied by urban zones.

In Figure 2(B) the hydrographs of Ravine Morro Blanc are represented. In this ravine, there is an important difference between both situations studied, and the peak discharge in their mouth is considerably higher nowadays. This could be related with the unsustainable urban development in the basin during the recent years.

Hydrographs calculated in Ravines Enmig and Morro Blanc outfalls are depicted in Figures 3(A) and (B) respectively. For both ravines, the peak water level is higher at present situation than at initial situation. These results again show that a high increase of urban areas in the basins, produces greater water 

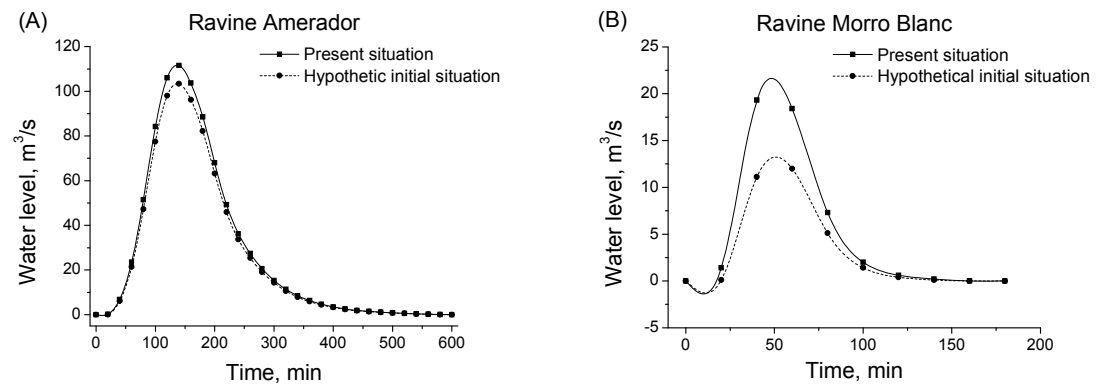

Figure 2: (A) Hydrographs obtained in the mouth of Ravine Amerador for present (continuous line with square symbols) and hypothetic initial situation (dashed line with circular symbols). (B) Hydrographs obtained in the mouth of Ravine Morro Blanc for both situations studied (the lines have the same meaning as on Ravine Amerador).
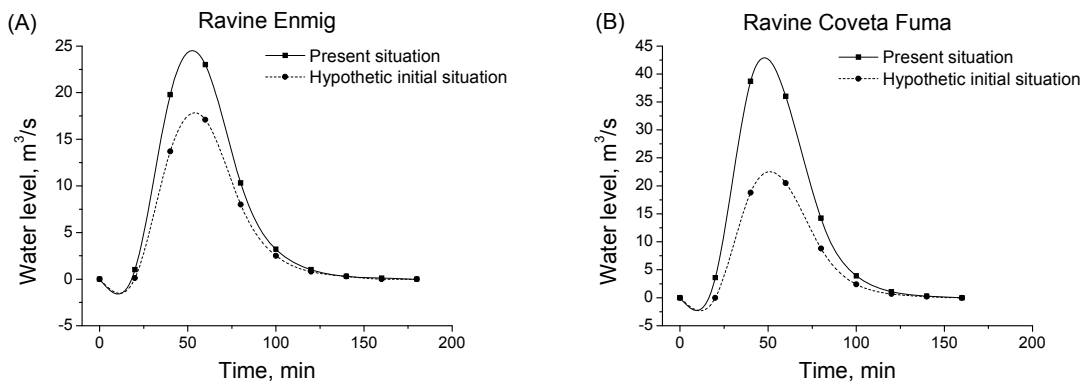

Figure 3: (A) Hydrographs obtained in the mouth of Ravine Enmig. (B) Hydrographs obtained in the mouth of Ravine Coveta Fuma. The lines have the same meaning as in Figure 2.

levels and, as a consequence, a rise of flood threaten in zones close to the mouth of ravines.

The results determined for Ravine Aguas are shown in Figure 4(A). Hydrographs obtained for this basin are very similar, because nowadays only a very small area of this basin is occupied by urban zones. La Solana basin is another example of increase of flood threaten, as a consequence of urban development, as can be observed in Figure 4(B).

Hydrographs calculated in the outfall of Ravines Baeza and Lanuza are represented in Figures 5(A) and (B). In both cases, there is an important rise of peak discharge between initial situation, without urban areas on basins, and present situation.

Finally, in Table 6 a compilation of peak water levels obtained from SCS hydrographs using HEC-HMS software for each ravine and situation studied is increase of water levels due to proliferation of urban zones, which occupy an 

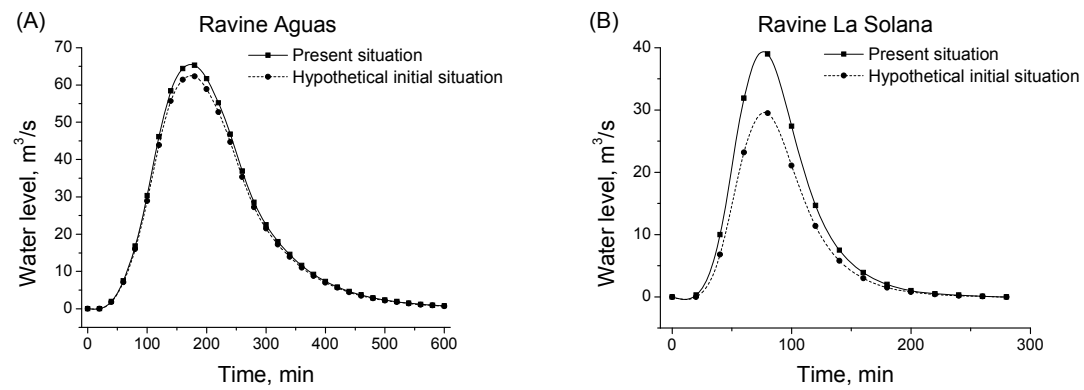

Figure 4: (A) Hydrographs obtained in the mouth of Ravine Aguas. (B) Hydrographs obtained in the mouth of Ravine La Solana. The lines have the same meaning as in Figure 2.
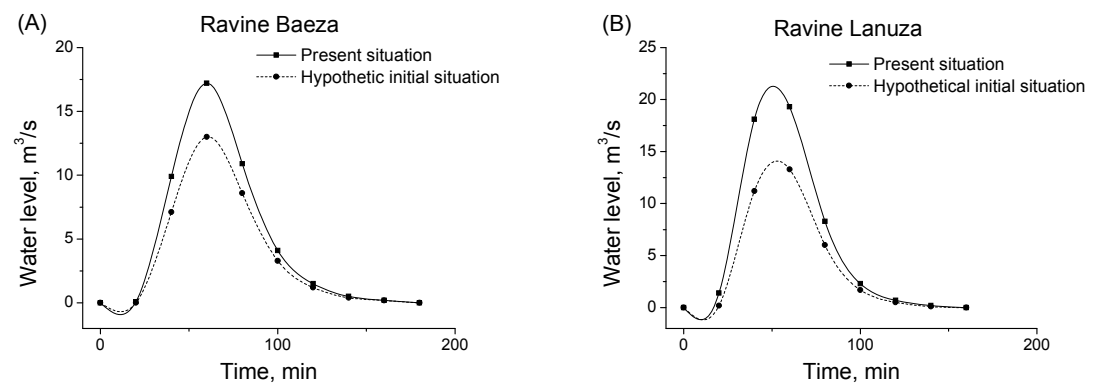

Figure 5: (A) Hydrographs obtained in the mouth of Ravine Baeza. (B) Hydrographs obtained in the mouth of Ravine Lanuza. The lines have the same meaning as in Figure 2.

Table 6: Water levels in outfalls of ravines obtained from SCS hydrographs using HEC-HMS software for a return period of 100 years.

\begin{tabular}{|c|c|c|}
\hline Ravine & $\begin{array}{c}\text { Water level } \\
\text { Hypothetical initial } \\
\text { situation }\left(\mathrm{m}^{3} / \mathrm{s}\right)\end{array}$ & $\begin{array}{c}\text { Water level } \\
\text { Present situation }\left(\mathrm{m}^{3} / \mathrm{s}\right)\end{array}$ \\
\hline Amerador & 103.4 & 112.7 \\
\hline Morro Blanc & 12 & 19.4 \\
\hline Enmig & 17.1 & 23.1 \\
\hline Coveta Fuma & 20.5 & 39 \\
\hline Aguas & 62.3 & 66.3 \\
\hline La Solana & 29.5 & 39.4 \\
\hline Baeza & 13 & 17.4 \\
\hline Lanuza & 13.3 & 19.4 \\
\hline
\end{tabular}


important part of the basins. This situation could provoke an important rise of flood threaten on these basins, mainly on coastline, which is where there is a higher concentration of urban areas and population.

\section{Conclusions}

The main conclusions that can be obtained from the results previously discussed can be summarized as follows:

- Most of basins placed in the studied zone, have a surface less than $3 \mathrm{~km}^{2}$ and their average slope is higher than $10 \%$.

- Touristic development has produced that part of these basins is occupied by urban zones. These changes have provoked that impermeable areas of basins increase and turnoff thresholds decrease.

- Impermeable area rate at present moment is very high in most of studied basins, which shows a typical case of unsustainable urban development.

- Peak discharge for each ravine increase between hypothetical initial situation, without urban zones in their basin, and present situation for both methods used.

- Water levels obtained using HEC-HMS software are higher than those calculated according to the rational method. These differences could be related to different duration of rainfalls considered for each method.

- Flood threaten is increased as a consequence of urban development.

- As a preliminary conclusion, it could be expected that an unsustainable urban development produces an increase of flood threaten. This statement is particularly true in case of Costa Blanca, and in general in the southeastern coast of Spain, due to their geographic and climate features.

\section{Acknowledgement}

J. M. Ortega is indebted to the Ministerio de Educación of Spain for a fellowship of the "Formación Personal Investigador (FPI)" programme (reference BES2008-002650).

\section{References}

[1] Rozalis, S., Morin, E., Yair, Y., Price, C., Flash flood prediction using an uncalibrated hydrological model and radar rainfall data in a Mediterranean watershed under changing hydrological conditions. Journal of Hydrology. 394(1-2), pp. 245-255, 2010.

[2] Quintana, P., Ribes, A., Martin, E., Habets, F., Boe, J., Comparison of three downscaling methods in simulating the impact of climate change on the hydrology of Mediterranean basins. Journal of Hydrology. 383(1-2), pp. 111-124, 2010. 
[3] Latron, J., Gallart, F., Seasonal dynamics of runoff-contributing areas in a small Mediterranean research catchment (Vallcebre, Eastern Pyrenees). Journal of Hydrology. 383(1-2), pp. 111-124, 2010.

[4] Gil Olcina, A., Olcina Cantos, J., Rico Amorós, A.M., Aguaceros, aguaduchos e inundaciones en áreas urbanas alicantinas. Universidad de Alicante. 2004.

[5] Mapa Geológico de España (E1:50.000). Hoja geológica MAGNA, $n^{\circ} 872-$ 874. IGME, Madrid. $2^{\mathrm{a}}$ serie. $1^{\mathrm{a}}$ edición, 1979.

[6] Ceballos-Barbancho, A., Morán-Tejeda, E., Luengo-Ugidos, M., LlorentePinto, J.M., Water resources and environmental change in a Mediterranean environment: The south-west sector of the Duero river basin (Spain). Journal of Hydrology. 351(1-2), pp. 126-138, 2008.

[7] Delgado, J., Llorens, P., Nord, G., Calder, I.R., Gallart, F., Modelling the hydrological response of a Mediterranean medium-sized headwater basin subject to land cover change: The Cardener River basin (NE Spain). Journal of Hydrology. 383(1-2), pp. 125-134, 2010.

[8] España Dirección General de Carreteras. Máximas lluvias diarias en la España peninsular. Ministerio de Fomento. Madrid, 1999.

[9] España Dirección General de Carreteras. Instrucción 5.2-IC "Drenaje superficial". Ministerio de Obras Públicas y Urbanismo. Madrid, 1990.

[10] Diputación de Alicante, Ciclo Hídrico, GESPLAN, www.gesplanweb.com/ alicante

[11] Temez, J.R., Extended and improved rational method. Version of Highways Administration of Spain. Proc. XXIV Congress IAHR, Madrid vol. A, pp 33-40. 1991.

[12] Hydrologic Engineering Center. HEC-HMS Hydrologic Modelling System: User's Manual, Version 3.4. US Army Corps of Engineers. Davis, 2009. 